Eur. J. Clin. Chem. Clin. Biochem.

Vol. 29, 1991, pp. 487-492

(C) 1991 Walter de Gruyter \& Co. Berlin - New York

\title{
Inhibition of Acetylcholinesterase Activity in Human Brain Tissue and Erythrocytes by Galanthamine, Physostigmine and Tacrine
}

\author{
By T. Thomsen ${ }^{1}$, B. Kaden ${ }^{2}$, J. P. Fischer ${ }^{1}$, U. Bickel ${ }^{1}, H$. Barz $^{3}$, G. Gusztony ${ }^{4}$, J. Cervos-Navarro ${ }^{4}$ \\ and $H$. Kewitz ${ }^{1}$ \\ 1 Institut für Klinische Pharmakologie, Klinikum Steglitz, Freie Universität Berlin \\ 2 Abteilung für Neurochirurgie, Klinikum Steglitz, Freie Universität Berlin \\ 3 Abteilung für Neurologie und Psychiatrie, Fachkrankenhaus Lichtenberg, Berlin \\ ${ }^{4}$ Institut für Neuropathologie, Klinikum Steglitz, Freie Universität Berlin
}

(Received March 20/June 11, 1991)

Summary: Galanthamine, physostigmine and 9-amino-1,2,3,4-tetrahydroacridine (tacrine) were evaluated as inhibitors of human acetylcholinesterase activity from samples of postmortem human brain, fresh brain cortex biopsies and human erythrocytes. Acetylcholinesterase activity was most effectively inhibited in all tissues by physostigmine, followed by tacrine and galanthamine. The respective inhibitor concentrations exerting a half maximal effect $\left(\mathrm{IC}_{50}\right)$ on acetylcholinesterase in postmortem human brain frontal cortex were $14 \mathrm{nmol} / \mathrm{l}$, $1.0 \mu \mathrm{mol} / 1$ and $3.2 \mu \mathrm{mol} / 1$ versus $15 \mathrm{nmol} / 1,1.1 \mu \mathrm{mol} / 1$ and $2.8 \mu \mathrm{mol} / 1$ in the hippocampus region. In addition, the inhibition of acetylcholinesterase by galanthamine was similar in postmortem brain and brain cortical biopsies from patients submitted to brain-tumour removal, indicating that postmortem changes up to $28 \mathrm{~h}$ after death probably did not influence the measurement of acetylcholinesterase inhibition. While physostigmine and tacrine acted equally on acetylcholinesterase from different sources, galanthamine was 10 -fold less potent in inhibiting the enzyme activity from human brain than from human erythrocytes. Comparison with issues from mice revealed that galanthamine was selectively more potent in suppressing acetylcholinesterase in human erythrocytes. The results are discussed in the light of pharmacokinetic data, and conclusions are drawn for further clinical studies.

\section{Introduction}

Reversible cholinesterase inhibitors are currently used for symptomatic treatment of cognitive deficits and memory impairment in Alzheimer's disease. One postulated mechanism is restoration of the cholinergic deficit at synaptic sites in the brain by inhibition of acetylcholine metabolism (1), but several other mech: anisms have also been discussed $(2-5)$. It was the purpose of this study to measure the inhibition of acetylcholinesterase ${ }^{1}$ ) from various sources by galanthamine, physostigmine and tacrine. A series of concentration response trials was performed using human brain tissue; and, prior to further specified analysis currently in progress, two separate regions of interest

1) Enzymes: Acetylcholinesterase, EC 3.1.1.7 in Alzheimer's disease were determined: the frontal cortex and the hippocampus. Since measurement of red-cell acetylcholinesterase inhibition ex vivo may predict enzyme inhibition in the brain $(6,7)$, it seemed useful to perform additional in vitro experiments with erythrocytes. Postmortem acetylcholinesterase activity has been shown to be stable (8) for at least $31 \mathrm{~h}$. It has also been reported, however, that the $4 \mathrm{~S}$ and $10 \mathrm{~S}$ molecular forms in the brain are extremely labile and that freezing of either subcellular or intact tissue causes dramatic shifts in the level of the molecular forms (9), although the molecular shift was not associated with any change of total acetylcholinesterase activity. To identify possible alterations in postmortem tissue, the inhibition of acetylcholinesterase by galanthamine in fresh human brain cortex samples

Eur. J. Clin. Chem. Clin. Biochem. / Vol. 29, 1991 / No. 8 
obtained at biopsies in 4 patients during brain-tumour ablation was also studied. In addition, the inhibitory effects of galanthamine, physostigmine and tacrine on acetylcholinesterase in vitro were also measured in erythrocytes and fresh brain tissue samples of animals.

\section{Materials and Methods}

Postmortem human brain tissue from the frontal cortex and hippocampal region of 11 individuals without evidence of psychiatric illnesses ( 7 female, 4 male, age 56-87) was dissected $5-28 \mathrm{~h}$ after death, frozen and stored at $-70^{\circ} \mathrm{C}$ until examination. Neuropathological examination of matching samples ensured that the patients showed no evidence of specific neurological illness. Fresh surgical samples of human cortex were obtained from 4 patients where such tissue was removed to gain access to the tumour (10). The non-tumorous (peritumorous) tissue was immediately frozen and stored as described above. Aliquots of laboratory routine whole blood samples were taken from the same patients prior to the surgical procedure, centrifuged and the red cells separated. Adult male NMRI-mice (bred by the Bundesgesundheitsamt Berlin and kept under standardized conditions) were killed by decapitation; trunk blood was collected in heparinized plastic tubes and mixed immediately. Whole blood was centrifuged, and the red cells were separated as above. Erythrocytes were haemolysed by freezing and thawing 3 times using liquid nitrogen. Brain samples were weighed and homogenized using an Ultra Turrax (Janke und Kunkel, Staufen, Germany) for $20 \mathrm{~s}$ at $20000 \mathrm{~min}^{-1}$ in 3 volumes of ice-cold Sörensen's phosphate buffer. The catalytic activity of acetylcholinesterase in erythrocytes and brain was measured as previously described in detail $(11,12)$, using $\left[{ }^{14} \mathrm{C}\right]$ acetylcholine iodide (NEN, Dreieich, Germany) radiolabelled in the acetyl moiety at a final substrate concentration of $3.6 \mathrm{mmol} / \mathrm{l}$, a pH of 7.4 and a temperature of $25^{\circ} \mathrm{C}$. Concentration response trials were performed as previously described $(11,12)$. The inhibitors used were galanthamine Nivalin $^{\mathrm{TM}}$, Waldheim, Vienna, Austria), tetraisopropylpyrophosphoramide (iso-OMPA, Sigma, Deisenhofen, Germany), physostigmine (Serva, Heidelberg, Germany) and tacrine (Serva, Heidelberg, Germany). After incubation of the sample with the inhibitor for $60 \mathrm{~min}$ at $25^{\circ} \mathrm{C}$ in vitro, the catalytic reaction was started by the addition of substrate.

\section{Statistical Analysis}

Calculations were performed using the statistical programs 'Stat 5.3' by Gary Perlman, University of California, San Diego, and a non-linear regression program by Koeppe \& Hamann (13) based on the least squares method, which was run on a Siemens $\mathrm{MX}-2$ microcomputer. The concentrations required to achieve $20-80 \%$ inhibition of the enzyme activity were calculated from the fitted concentration response using an empirically modified Hill equation with the following set of parameters:

$$
I=\frac{a}{\left(\frac{b}{c}\right)^{c}+1}+d \cdot \log c+e
$$

\section{Results}

Butyrylcholinesterase activity was selectively inhibited by $0.1 \mathrm{mmol} / 1$ tetraisopropylpyrophosphoramide in some samples of postmortem human brain cortex and hippocampus; this did not inhibit acetylcholinesterase in the assay used, as demonstrated in earlier investi- gations (11), or change the concentration response of total cholinesterase activity to galanthamine, physostigmine and tacrine, indicating that the catalytic activity of cholinesterase in the human brain samples was almost completely related to acetylcholinesterase activity. To avoid interactions, between tetraisopropylpyrophosphoramide and a second inhibitor, the subsequent concentration-response trials were performed without specific inhibition of butyrylcholinesterase activity.

Assays of frontal cortex and hippocampal samples revealed 2- to 3-fold higher acetylcholinesterase activities in the latter, as reported by other authors $(8,14)$. No significant differences, however, were seen between the two regions with respect to the inhibition of acetylcholinesterase activity by galanthamine, physostigmine or tacrine (fig. 1; tab. 1). Acetylcholinesterase activity in the human brain frontal cortex tissue obtained at autopsy was inhibited over a range of $20-80 \%$ most effectively by physostigmine $(3-74$ $\mathrm{nmol} / \mathrm{l})$, followed by tacrine at between $210 \mathrm{nmol} / 1$ and $4.0 \mu \mathrm{mol} / \mathrm{l}$ and galanthamine at between 650 $\mathrm{nmol} / \mathrm{l}$ and $17.8 \mu \mathrm{mol} / 1$ (fig. 1 ; tab. 1). Human brain temporal cortex tissue and the frontal cortex homogenate showed identical inhibition by physostigmine (fig. 1; tab. 2). Comparison of fresh brain cortex biopsies with postmortem cortex tissue revealed the same inhibitory response to galanthamine. Red-cell cholinesterase activity in blood samples from the neu=
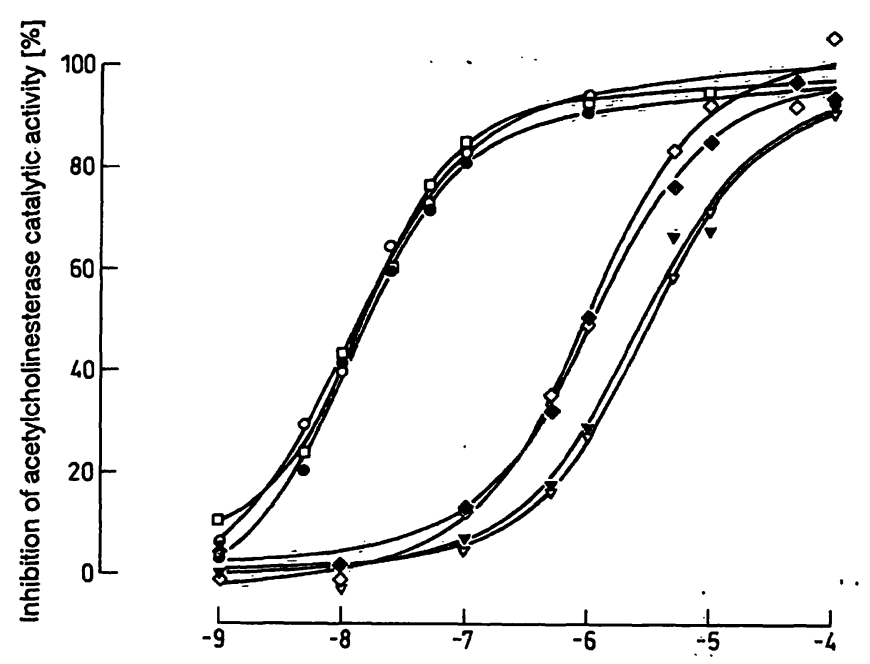

log Inhibitọr concentration [mol/l]

Fig. 1. Concentrations of between $1 \mathrm{nmol} / \mathrm{l}$ and $0.1 \mathrm{mmol} / \mathrm{l}$ of galanthamine $(\nabla, \nabla)$, physostigmine $(0, \bullet, \square)$, and tacrine $(\diamond, \diamond)$ were incubated for $1 \mathrm{~h}$ at $25^{\circ} \mathrm{C}$ in vitro with samples of human brain cortex of the frontal (o, $\diamond, \nabla)$ or temporal $(\bullet)$ region and human brain hippocampus $(\square, \diamond, \nabla)$ before the reaction was started by adding substrate. Values represent the mean inhibition in postmortem homogenate samples from $6-11$ different patients at autopsy with less than $28 \mathrm{~h}$ delay. Mean values were derived from the averages of dupliçate assays. 
Tab. 1. Inhibition of acetylcholinesterase activity in human brain tissue

\begin{tabular}{|c|c|c|c|c|c|c|c|c|c|c|c|c|c|c|}
\hline \multirow[t]{2}{*}{ Tissue } & \multirow[t]{2}{*}{$\mathbf{n}$} & \multirow[t]{2}{*}{ Inhibitor } & \multicolumn{12}{|c|}{ Inhibitor concentration [nmol/1] } \\
\hline & & & $\overline{1}$ & 5 & 10 & 25 & 50 & 100 & 500 & 1000 & 5000 & 10000 & 50000 & 100000 \\
\hline $\begin{array}{l}\text { Frontal } \\
\text { Cortex }\end{array}$ & 9 & Physostigmine & $\begin{array}{c}6.2 \\
(2.4)\end{array}$ & $\begin{array}{c}29.8 \\
(1.6)\end{array}$ & $\begin{array}{c}40.3 \\
(2.7)\end{array}$ & $\begin{array}{c}65.2 \\
(1.2)\end{array}$ & $\begin{array}{l}73.7 \\
(2.4)\end{array}$ & $\begin{array}{c}83.6 \\
(2.2)\end{array}$ & & $\begin{array}{c}94.8 \\
(2.4)\end{array}$ & & & & \\
\hline $\begin{array}{l}\text { Hippo- } \\
\text { campus }\end{array}$ & 10 & Physostigmine & $\begin{array}{c}10.6 \\
(2.0)\end{array}$ & $\begin{array}{l}24.2 \\
(2.7)\end{array}$ & $\begin{array}{c}43.6 \\
(2.3)\end{array}$ & $\begin{array}{c}60.5 \\
(2.8)\end{array}$ & $\begin{array}{c}76.9 \\
(1.9)\end{array}$ & $\begin{array}{c}86.0 \\
(2.5)\end{array}$ & & $\begin{array}{c}93.9 \\
(1.4)\end{array}$ & & $\begin{array}{l}95.8 \\
(2.0)\end{array}$ & & \\
\hline $\begin{array}{l}\text { Frontal } \\
\text { Cortex }\end{array}$ & 9 & Tacrine & $\begin{array}{r}-0.7 \\
(0.7)\end{array}$ & & $\begin{array}{c}-1.1 \\
(5.1)\end{array}$ & & & $\begin{array}{c}12.9 \\
(2.0)\end{array}$ & $\begin{array}{c}35.7 \\
(1.9)\end{array}$ & $\begin{array}{c}49.9 \\
(2.8)\end{array}$ & $\begin{array}{l}84.2 \\
(2.9)\end{array}$ & $\begin{array}{l}93.1 \\
(3.9)\end{array}$ & $\begin{array}{c}92.5 \\
(2.3)\end{array}$ & $\begin{array}{l}106 \\
(7.6)\end{array}$ \\
\hline $\begin{array}{l}\text { Hippo- } \\
\text { campus }\end{array}$ & 10 & Tacrine & $\begin{array}{c}4.8 \\
(3.5)\end{array}$ & & $\begin{array}{l}2.4 \\
(2.9)\end{array}$ & & & $\begin{array}{c}13.4 \\
(1.5)\end{array}$ & $\begin{array}{l}32.1 \\
(2.6)\end{array}$ & $\begin{array}{l}51.2 \\
(2.5)\end{array}$ & $\begin{array}{l}76.8 \\
(3.1)\end{array}$ & $\begin{array}{c}85.7 \\
(1.8)\end{array}$ & $\begin{array}{c}97.2 \\
(2.5)\end{array}$ & $\begin{array}{c}94.3 \\
(1.6)\end{array}$ \\
\hline $\begin{array}{l}\text { Frontal } \\
\text { Cortex }\end{array}$ & 11 & Galanthamine & $\begin{array}{c}5.6 \\
(4.9)\end{array}$ & & $\begin{array}{c}-2.3 \\
(3.8)\end{array}$ & & & $\begin{array}{c}4.9 \\
(2.1)\end{array}$ & $\begin{array}{c}16.7 \\
(2.7)\end{array}$ & $\begin{array}{l}27.7 \\
(2.1)\end{array}$ & $\begin{array}{l}59.0 \\
(2.8)\end{array}$ & $\begin{array}{c}71.9 \\
(1.5)\end{array}$ & & $\begin{array}{c}91.5 \\
(1.1)\end{array}$ \\
\hline $\begin{array}{l}\text { Hippo- } \\
\text { campus }\end{array}$ & 10 & Galanthamine & $\begin{array}{l}0.0 \\
(2.5)\end{array}$ & & $\begin{array}{l}2.2 \\
(2.5)\end{array}$ & & & $\begin{array}{l}7.3 \\
(2.8)\end{array}$ & $\begin{array}{c}18.1 \\
(2.2)\end{array}$ & $\begin{array}{c}29.9 \\
(1.4)\end{array}$ & $\begin{array}{c}66.8 \\
(2.0)\end{array}$ & $\begin{array}{c}68.3 \\
(4.0)\end{array}$ & & $\begin{array}{c}93.1 \\
(1.1)\end{array}$ \\
\hline
\end{tabular}

Concentration response for inbibition by $1 \mathrm{nmol} / 1$ to $0.1 \mathrm{mmol} / 1$ of physostigmine, tacrine and galanthamine, which were incubated for $1 \mathrm{~h}$ at $25^{\circ} \mathrm{C}$ in vitro with $\mathrm{n}$ different samples of postmortem human brain tissue. Mean values of enzyme inhibition (\% of uninhibited control) and the standard error of the mean (in brackets) are given.

rosurgery patients, however, was 10 times more strongly inhibited by galanthamine than the respective enzyme activity in brain tissue samples. This intraindividual comparison reflected the same differences as those between human postmortem brain tissue and acetylcholinesterase inhibition in red cells of 8 healthy male volunteers of an earlier trial ((12); fig. 2). In contrast to galanthamine, each of the cholinesterase inhibitors, physostigmine and tacrine, diminished enzyme activities in human brain tissue and human erythrocytes to the same degree. Concentrations of the inhibitors exerting a hạlf-maximal effect $\left({ }^{\prime} C_{50}\right.$ values) on acetylcholinesterase of various sources are summarized in table 2 . Evaluation of acetylcholines- terase activity in the brain cortex homogenate and erythrocytes of NMRI-mice resulted in a slope of the concentration response curve, which was flatter than that in human tissues, as described above. However, the red cells and brain of NMRI-mice showed no relevant differences in acetylcholinesterase inhibition (fig. 3; tab. 2).

\section{Discussion}

In this study, physostigmine was found to be more potent than tacrine and galanthamine in suppressing cholinesterase activity in the human brain. The data correspond very well to those of a similar trial (5), in

Tab. 2. IC $\mathrm{CQ}_{50}$ of various acetylcholinesterase inhibitors

\begin{tabular}{|c|c|c|c|c|c|c|c|c|c|}
\hline Species & Group & Tissue & Region & (n) & $\begin{array}{l}\text { Physo- } \\
\text { stigmine }\end{array}$ & (n) & Tacrine & (n) & $\begin{array}{l}\text { Galan- } \\
\text { thamine }\end{array}$ \\
\hline Humanan & Postmortem & Brain & $\begin{array}{l}\text { Hippo- } \\
\text { campus }\end{array}$ & (10) & 15 & (10) & 1070 & (10) & 2750 \\
\hline Human & Postmortem & Brain & $\begin{array}{l}\text { Frontal } \\
\text { Cortex }\end{array}$ & (9) & 14 & (9) & 950 & (11) & 3240 \\
\hline Human & Postmortem & Brain & $\begin{array}{l}\text { Temporal } \\
\text { Cortex }\end{array}$ & (6) & 16 & & & & \\
\hline Human & Neurosurgery & Brạin & Cortex & & & & & (4) & 2900 \\
\hline Human & Neưrosurgery & Erythrocyte & & & & & & (4) & 370 \\
\hline Human & Volunteer & Erythrocyte & & (7) & 27 & (8) & 1590 & (8) & 360 \\
\hline Mouse & Decapitation & Brain & Cortex & (5) & 63 & (5) & 1290 & (5) & 4400 \\
\hline Mouse & Deçapitation & Erythrocyte & & (5) & 68 & (5) & 1230 & (5) & 5100 \\
\hline
\end{tabular}

Physostigmine, tacrine and galanthamine were incubated for $1 \mathrm{~h}$ at $25^{\circ} \mathrm{C}$ in vitro with $\mathrm{n}$ different samples of various tissues. The inhibitor concentrations (nmol/l) producing a half-maximal effect $\left(\mathrm{IC}_{50}\right)$ on acetylcholinesterase were derived from a plot of \% enzyme inhibition versus log concentration of inhibitor. 

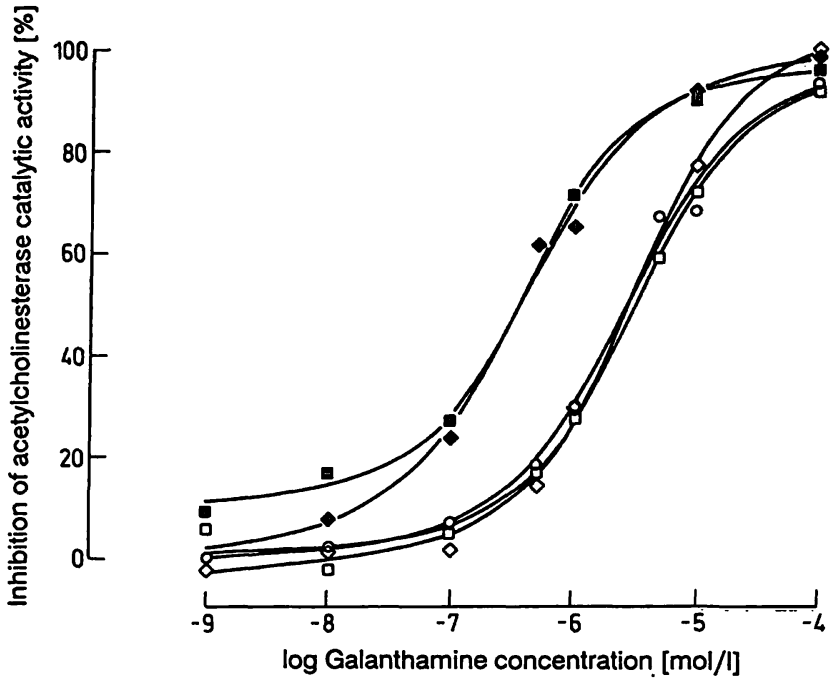

Fig. 2. Comparison of the inhibitory effects of galanthamine on acetylcholinesterase activity in human brain tissue and human erythrocytes in vitro. Human brain tissue was obtained at autopsy less than $28 \mathrm{~h}$ postmortem from 2 regions, frontal cortex $(\square)$ and hippocampus (o), or as fresh tissue during neurosurgical removal $(\diamond)$ of a brain itumour. Human red cells were obtained from healthy volunteers ( $\square)$ and the respective neurosurgical patients $(\Delta)$ before the induction of anaesthesia. Assay conditions as stated in figure 1 . Values represent the mean inhibition of 4 (neurosurgery group), $10=11$ (postmortem group), and 7 or 8 (volunteers) samples.

which Perry and colleagues used physostigmine and tacrine in samples of postmortem parietal cortex obtained after an equal autopsy delay from 3 individuals with no clinical or pathological evidence of any neurological or psychiatric disorder. There are minor differences between the two reports, i.e. they found tacrine to be 1.5 times more and physostigmine 2 times less potent than we did. Both cholinesterase inhibitors have been widely used in vivo, but relatively few studies have reported plasma/serum concentrations of physostigmine $(15-17)$ or tacrine $(18-20)$. The doses were increased until adverse peripheral effects in the majority of the respective patients or volunteers indicated the upper tolerance level. These concentrations were in the range of $11-25 \mathrm{nmol} / \mathrm{l}$ with physostigmine (15) and 60-220 nmol/1 with tacrine (18). Peak galanthamine concentrations after intravenous application of $0.3 \mathrm{mg} / \mathrm{kg}$ body weight in anaesthetized patients were $1890 \mathrm{nmol} / \mathrm{l}$ (21), while drug concentrations in plasma $2 \mathrm{~h}$ after chronic oral administration of $15 \mathrm{mg}$ three times daily in Alzheimer patients (22) were in the range of $400-550 \mathrm{nmol} / \mathrm{l}$.

According to our data (fig. 1; tab. 1; tab. 2), these measured plasma concentrations would not result in high degrees of central cholinesterase inhibition. It has been reported, however, that galanthamine, physostigmine and tacrine accumulate in the brain tissue of small animals. If this occurs to an equal extent in

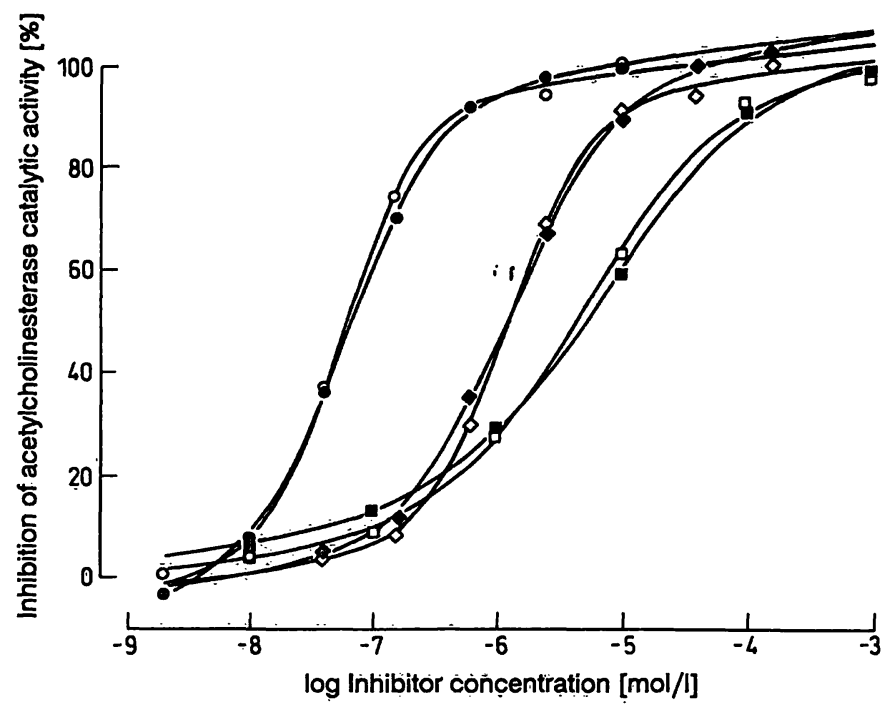

Fig. 3. Concentrations of between $0.5 \mathrm{nmol} / \mathrm{l}$ and $0.5 \mathrm{mmol} / \mathrm{l}$ of galanthamine $(\square, v)$, physostigmine $(0, \bullet)$ and tacrine $(\diamond, \diamond)$ were incubated for $1 \mathrm{~h}$ at $25^{\circ} \mathrm{C}$ in vitro with samples of NMRI-mice brain cortex (open symbols) and erythrocytes (filled symbols). Values represent the mean of $n=5$ different samples.

humans, physostigmine might be increased 2-fold (23, 24) and tacrine 8-12-fold (25), resulting in an estimated acetylcholinesterase inhibition of $65 \%$ and $75 \%$ respectively. In the case of galanthamine (26), the accumulation factor of 2 would only lead to a $25-35 \%$ enzyme inhibition in the human brain. This finding may be explained by the fact that galanthamine, in contrast to physostigmine and tacrine, was markedly less potent in suppressing acetylcholinesterase activity in the human brain than in human red cells. One might speculate whether galanthamine separated between different molecular G-forms of acetylcholinesterase (erythrocytes dimeric; brain tetrameric), while physostigmine and tacrine did not, as was recently shown for the $G_{1}$ and $G_{4}$ form using the latter 2 compounds (27). There were no differences in enzyme inhibition by galanthamine, physostigmine and tacrine, however, between erythrocytes and brain tissue of mice.

In vitro measurement of cholinesterase inhibition in tissue homogenates may not reliably reflect true drug concentrations, true inhibition of acetylcholinesterase activity or in vivo alterations at synaptic sites in the brain. In addition, the rate of appearance and the effects of various metabolites of the cholinesterase inhibitors are still unclear. Moreover, it has been reported that, in Alzheimer patients, the location of cholinesterases has largely shifted to the neuritic plaques and tangles (28), giving rise to the speculation that cholinesterase-inhibiting drugs may act differently in an Alżheimer brain than in a non-demented one. And finally, although there is some evidence on the relationship between enzyme inhibition and 
changes in acetylcholine content or turnover $(25,29$, 30 ), the degree of acetylcholinesterase inhibition required to elicit central effects in the human brain is still unknown.

Despite all of these serious limitations, some conclusions, however, may be drawn from the current data:

1. Inhibition of catalytic enzyme activity in erythrocytes, as measured ex vivo in the patient, is a fairly close predictor of cholinesterase inhibition in the brain if physostigmine or tacrine have been given. The measurement of peripheral acetylcholinesterase activity after galanthamine application may be used as a safety parameter and estimate of central inhibition.

2. Clinical studies on the efficacy of reversible cholinesterase inhibitors should employ an individual dose finding phase according to the report of a consensus conference on the methodology of clinical trials of "nootropics" (31) and, in addition, include the concomitant degree of ex vivo enzyme inhibition. The lower doses of galanthamine, physostigmine and tacrine used so far in many clinical studies possibly did not cause the anticipated degrees of inhibition of brain acetylcholinesterase activity, and this would explain in part the limited effect.

3. Ex vivo measurement of enzyme inhibition should be performed as soon as possible during clinical investigation to verify the in vitro findings.

\section{Acknowledgement}

The authors wish to thank J. Weirowski, Ph. D., for help in preparing the manuscript. The valuable technical assistance of Mrs. H. Müller and Mrs. G. Siebert is also gratefully acknowledged. Galanthamine hydrobromide was kindly supplied by Waldheim, Vienna, Austria.

\section{References}

1. Bartus, R. T., Dean, R. L. \& Flicker, C. (1987) Cholinergic psychopharmacology: An integration of human and animal research on memory. In: Psychopharmacology, Chapter 22 (Meltzer, H. Y., ed.), pp. 219-232, Raven Press, New York.

2. Albin, R. L., Young, A. B. \& Penney, J. B. (1988) Tetrahydro-9-aminoacridine (THA) interacts with the phencyclidine (PCP) receptor site. Neurosci. Lett. 88, 303-307.

3. Nilsson, L., Adem, A., Hardy, J., Winblad, B. \& Nordberg, A. (1987) Do tetrahydroaminoacridine and physostigmine restore acetylcholine release in Alzheimer brains via nicotinic receptors. J. Neural Transm. 70, 357-368.

4. Osterrieder, W. (1987) 9-amino-1,2,3,4-tetrahydroacridine (THA) is a potent blocker of cardiac potassium channels. Br. J. Pharmacol. 92, $521=525$.

5. Perry, E. K., Smith, C. J., Court, J. A., Bonham, J. R., Rodway, M. \& Atack, J. R. (1988) Interaction of 9-amino1,2,3,4-tetrahydroaminoacridine (THA) with human cortical nicotinic and muscarinic receptor binding in-vitro. Neurosci. Lett. $91,211-216$.

6. Sherman, K. A. \& Messamore, E. (1988) Blood cholinesterase inhibitions as a guide to the efficacy of putative therapies for Alzheimer's dementia. Comparison of tacrine and physostigmine. In: Current Research in Alzheimer Therapy (Giacobini, E. \& Becker, R., eds.), pp. 73-86, Taylor and Francis, New York.

7. Thomsen, T., Kewitz, H. \& Pleul, O. (1988) Estimation of cholinesterase activity (EC 3.1.1.7; 3.1.1.8) in undiluted plasma and erythrocytes as a tool for measuring in vivo effects of reversible inhibitors. J. Clin. Chem. Clin. Biochem. 26, 469-475.

8. Atack, J. R., Perry, E. K., Bonham, J. R., Candy, J. M. \& Perry, R. H. (1986) Molecular forms of acetylcholinesterase and butyrylcholinesterase in the aged human central nervous system. J. Neurochem. 47, 263-277.

9. Payner, T. D., Drake, R. L., Saker, D. M. \& Shipley, M. T. (1987) Determination of molecular forms of brain acetylcholinesterase: Technical considerations. Brain Res. Bull. $19,287-290$.

10. Nicoletti, F., Canoncio, P. L., Favit, A., Nicoletti, G. \& Albanese, V. (1989) Receptor-mediated stimulation of insitol phospholipid hydrolysis in human brain. Eur. J. Pharmacol. 160, 299-301.
11. Thomsen, T., Kewitz, H. \& Pleul, O. (1989) A suitable method to monitor inhibition of cholinesterase activities in tissues as induced by reversible enzyme inhibitors. Enzyme $42,219-224$.

12. Thomsen, T. \& Kewitz, H. (1990) Selective inhibition of human acetylcholinesterase by galanthamine in vitro and in vivo. Life Sci. 46, 1553-1558.

13. Koeppe, P. \& Hamann, C. (1980) A program for non-linear regression to be used on desktop computers. Comp. Progr. Biomed. 12, 121-128.

14. Kewitz, H., Hanke, T. \& Hillebrand, J. (1980) Human brain weight and acetylcholinesterase in relation to aging. Neurochem. Int. 2, 209-213.

15. Hartvig, P., Lindstroem, B., Petterson, E. \& Wiklund, L. (1989) Reversal of postoperative somnolence using a tworate infusion of physostigmine. Acta Anaesthesiol. Scand. $33,681-685$.

16. Thal, L. J., Masur, D. M., Sharpless, N. S., Fuld, P. A. \& Davies, P. (1986) Acute and chronic effects of oral physostigmine and lecithin in Alzheimer's disease. Prog. Neuropsychopharmacol. Biol. Psychiatry 10, 627-636.

17. Whelpton, R. \& Hurst, P. (1985) Bioavailability of oral physostigmine. N. Engl. J. Med. 313, 1293-1294.

18. Fitten, L. J., Perryman, K. M., Gross, P. L., Fine, H., Cummins, J. \& Marshall, C. (1990) Treatment of Alzheimer's disease with short- and long-term oral THA and lecithin: A double blind study. Am. J. Psychiatry 147, 239242.

19. Forsyth, D. R., Wilcock, G. K., Morgan, R. A., Truman, C. A., Ford, J. M. \& Roberts, C. J. (1989) Pharmacokinetics of tacrine hydrochloride in Alzheimer's disease. Clin. Pharmacol. Ther. 46, 634-641.

20. Summers, W. K., Tachiki, K. H. \& Kling, A. (1989) Tacrine in the treatment of Alzheimer's disease. A clinical update and recent pharmacologic studies. Eur. Neurol. 29, Suppl. $3,28-32$.

21. Westra, P., van Thiel, M. J. S., Vermeer, G. A., Soeterbroek, A. M., Scaf, A. H. J. \& Claessens, H. A. (1986) Pharmacokinetics of galanthamine (a long-acting anticholinesterase drug) in anaesthethized patients. Br. J. Anaesth. 58. 13031307. 
22. Thomsen, T., Bickel, U., Fischer, J. P. \& Kewitz, H. (1990) Stereoselectivity of cholinesterase inhibition by galanthamine and tolerance in humans. Eur. J. Clin. Pharmacol. 39, $603-605$.

23. King, B. F. \& Somani. S. M. (1987) Distribution of physostigmine and metabolites in brain subcellular fractions of the rat. Life Sci. 41, 2007-2015.

24. Somani, S. M. \& Khalique, A. (1987) Pharmacokinetics and pharmacodynamics of physostigmine in the rat after intravenous administration. Drug Metab. Dispos. 15, 627633.

25. Nielsen. J. A., Mena, E. E., Williams, I. H., Nocerini, M. R. \& Liston, D. (1989) Correlation of brain levels of 9amino-1,2.3.4-tetrahydroacridine (THA) with neurochemical and behavioural changes. Eur. J. Pharmacol. 173, $53-64$.

26. Bickel, U., Thomsen. T., Fischer, J. P.. Weber, W. \& Kewitz, H. (1991) Galanthamine: Pharmacolinetics, tissue distribution and brain cholinesterase inhibition in mice. Neuropharmacol. 30. $44 \bar{\jmath}-454$.

27. Ogane, N., Messamore. E. \& Giacobini, E. (1991) Do cholinesterase inhibitors preferentially inhibit certain molecular forms of brain cholinesterase? Abstracts of Second international Springfield Symposium on Advances in $\mathrm{Alz}$ heimer Therapy, May 3-5. 1991, P43.
28. Mesulam, M. M., Geula, C. \& Moran, M. A. (1987) Anatomy of cholinesterase inhibition in Alzheimer's disease: effect of physostigmine and tetrahydroaminoacridine on plaques and tangles. Ann. Neurol. 22, 683-691.

29. Kewitz, H., Pleul, O. \& Mann, E. (1977) Pre- and postnatal development and drug-induced alterations of free and bound acetylcholine in rat brain. Naunyn-Schmiedeberg's Arch. Pharmacol. 298, 149-155.

30. Foldes, F. F., Szerb, J. C., Ludvig, N., Nitta, S., Lalezari, I. \& Potter, P. E. (1989) The anticholinesterase activity of aminopyrines, physostigmine, and tetrahydroaminoacridine, and their effect on evoked release of acetylcholine and glutamate from rat brain. In: Pharmacological interventions on central cholinergic mechanisms in senile dementia (Kewitz, H., Thomsen, T. \& Bickel, U., eds.) pp. 292-297, Zuckschwerdt, Mūnchen.

31. Amaducci, L., Angst, J., Bech, P., Benkert, O., Bruinvels, J., Engel, R. R., Gottfries, C. G., Hippius, H., Levy, R., Lingjaerde, O., López-Igor Jr., J. J., Orgogozo, J. M., Pull, C., Saletu, B., Stoll, K. D. \& Woggon, B. (1990) Consensus conference on the methodology of clinical trials of "nootropics", Munich, June 1989. Report of the concensus committee, Pharmacopsychiatry 23, 171-175.

Dr. T. Thomsen

Institut für Klinische Pharmakologie

Universitätsklinik Steglitz

Freie Universität Berlin

Hindenburgdamm 30

W-1000 Berlin 45

Bundesrepublik Deutschland 